\title{
International Marketing in Crises Situation in Turkey
}

\author{
Ilkay Karaduman \\ Department of Business Management, Istanbul Aydin University \\ P.O. Box 36000, Beşyol Mah, İnönü Cad, No. 38 Sefaköy-Küçükçekmece \\ Istanbul, Turkey \\ Tel: 02124441428 ext. $24801 \quad$ E-mail: ilkaykaraduman@aydin.edu.tr \\ Ovais Vohra \\ Department of Business Management, Istanbul Aydin University \\ PO Box 36000, Beşyol Mah, İnönü Cad, No. 38 Sefaköy-Küçükçekmece \\ Istanbul, Turkey
}

Tel: 02124441428 ext. 12816 E-mail: ovaisvohra@aydin.edu.tr

Received: May 7, 2015

doi:10.5296/wjbm.v1i1.7729
Accepted: May 26, 2015

Published: June 1, 2015

URL: http://dx.doi.org/10.5296/ wjbm.v1i1.7729

\begin{abstract}
This research study is conducted with the primary aim of exploring effective marketing strategies in times of crisis; using Turkey as a case study. The purpose of current study is to assess the crisis situation prevailed in Turkey The study focus on the crises situation in Turkey and recommend the number of different marketing strategies for Turkish companies in order to retain their market share in crises situation.

Turkey is the growing economy however bigger challenges still persist. Current account deficits are still looming large on Turkey with financial turmoil that is striking constant troubles. These problems need to be tackled along with outgrowing the local business with the help of strategic marketing and communication's plan to handle economic troubles, otherwise with these set of problems at hand, Turkey is likely to suffer even more in coming time.
\end{abstract}

The researcher has attempted to provide a number of recommended actions as suggestions that were primarily derived from a combination of secondary and primary research work undertaken within its fold. Through promoting positive features about an offered product and 


\section{Macrothink}

through converting bad promotional messages into good ones, the company can attract more customers and leads into a business. Price penetration strategy and other marketing strategies discussed that may help companies to maintain their market share in crises situation. The results of the study and the underlying survey identified the key areas of improvement in the Turkish investment climate; stating that strong regulatory frameworks, growth of the private sector and innovation policies along with employee generation are some recommended options that can go a long way in developing the markets.

Keywords: Marketing in Turkey, Crises impacts, Consumer response in crises, Marketing in crises situation 


\section{Introduction}

The concept of crisis management has gained immense significance in the recent times especially in the fields of marketing, communications and public relations. Crisis communication and management competencies are being greatly assessed by global companies molding or altering their current marketing strategies accordingly. In these times of economic sensitivity and vulnerability, this has become a vital component of risk management and strategies of business continuity. While some risks may be beyond a company's control, others can literally be foreseen. Against identifiable risks and crises, a proactive approach needs to be developed in all organizational departments including the marketing function. Such crises would only arise if companies fail to identify a contentious issue at hand, at a stage where it might be too difficult to tackle. Nevertheless, the impacts of such crises could definitely be minimized using effective marketing strategies and management abilities.

\subsection{International Marketing}

International marketing is referred to as the phenomenon that occurs when managers prepare global plans of marketing the goods and services on an international basis, targeting and positioning the products across a number of countries This may seem to be an easy task; but in reality, it is highly tedious and involves a lot of learning before a manager can embark on such a plan. There are a number of reasons why international marketing is significant in present time. Most companies feel limited growth opportunities within domestic markets. Their strategies and plans regarding effective target marketing does not seem to fully establish itself, unless they tap markets they have never been to, before. When a company plans to promote itself across geographic boundaries, it is actually attempting towards a global approach in marketing their products and bigger customer share). With greater market shares, come greater responsibilities to maintain product standards as per the quality assurance criterion of different countries in the developed and developing parts of the Globe. Global trade has resultantly leaped from few hundred billion dollars to a spectacular eighteen billion dollars in the current times (Fredrickson et al., 2003, p. 365).

\subsection{Core Concept of Marketing in Modern Environment}

Modern marketing embraces the concept of marketing that had been spread across the Globe since 1950s. As per the business philosophy, marketing is all about orienting a firm towards its customer's needs. Marketing relates closely to the concept of telling the customers what they want and what a company can offer in response to what they want. In such modern organizations, customer focus penetrates as the main focus from finance department to human resource management to administration and production. Market considerations form the basis of all decision-making within such organizations. This however, does not mean that marketing should be considered superior to other areas of business. It simply reflects that managers must not ignore marketing implication of their decisions. There are three basic propositions to the concept of marketing in modern environments: 


\subsubsection{Customer Focus}

Effective companies in today's world need to shift their focus from purely organizational approach to customer-centric. Successful marketing will only materialize if buyers' needs and wants are kept in sharp focus; while implementing strategies that are actually addressing or meeting those needs. Management guru Peter Drucker was of the view that marketers must be so proficient in understanding customer's needs that each of the company's products fits their needs and sells itself (Burnett, 1999, p. 481). Customers' experiences have always occupied much space in marketing literature in the contemporary world; customers are looking forward to multi-channel experiences where they want to have the best buying experience in the best price along with the features of a personalized service.

\subsubsection{Coordination}

An inter-related system of marketing activities known as the marketing mix must be well-planned and properly coordinated; aiming to meet the identified needs of the customers. This must be viewed as a whole, and aligned with other business activities (Chorafas, 2009, pp. 50-52).

\subsubsection{Profit Orientation}

In the light of profit planning, customer satisfaction should remain the central focus of today's organizations. In a quest to earn profits, the marketing significance and its alignment to key business strategy must not go unnoticed. Customer satisfaction, in light of marketing concepts in modern-day environments, is the real source of profitability for the marketers.

\subsection{Crisis Concepts in Economy (Turkey as a Case Study)}

A crisis in a complex system is a period wherein the system functions poorly, prompting for an immediate correction (Bifulco \& Brown, 1996, pp. 163-172). A period of dismal economic performance is therefore, known as a crisis in economic concept. During crises times, financial institutions drop in their progress and performance, while economic production is minimal and does not meet levels of demand. It is usually very complicated to determine factors that cause crisis, since they are mostly unpredictable and come as an unexpected occurrence (Amalia \& Ionut, 2009, p. 781). Crises include corporate lawsuits, downsizing, quality problems, government probes, boycotts, negative media coverage, product recalls, and strikes etc. Crisis management consists of three distinct phases: crisis prevention, response, and recovery. However, it is firstly essential to note the sensitive factors in economies that might lead to chaos and crisis. Financial institutions and other state departments must be mindful of managing factors leading towards crisis in the end. Being a complex system in itself, it is essential for chaotic activities to persist for longer periods of time before they could plague the economy and turn into a "crisis" (Amalia \& Ionut, 2009, p. 781).

Turkey has made significant progress in competitiveness and market rivalry in the past decade, jumping to number 41 in the Global Competitiveness Index. According to the world investment report 2014 Turkey has attracted more than 110 USD billion in last ten years and 
given ranked as the 14th most promising home country for FDI in 2014-2016 by investment promotion organizations. Moreover, Turkey's financial sector witnessed a boost followed by consistent financial reforms that made the country relatively steadfast amidst trying times. In the Organization for Economic Cooperation and Development (OECD), Turkey remains the only country that could not support the banking sector with private sector support in lieu of the crisis. However the increasing inflation rate since few times in Turkey and due to security giving facilitation to other countries migrants and other related issues Turkey is affecting from crises, So in this way it is essential to explore this subject and prepare any suitable strategic plan for marketers to do their job in most efficient way and may protect their organizations or minimize the crises impacts on their organizations.

\subsection{Role of Marketing in Crisis}

In understanding the role of marketing in crisis, it is essential to know that marketers can play a significant role in rebuilding the economy. It has been a common observation that in good times, marketing efforts for companies appear highly visible, while they tend to suffer from attention and lack of resources in times of financial instability. In periods marked by slow economic progress, marketers tend to go into a hibernation mode, whereby waiting when the company will allocate them budgets to work on (Köksal Özgül, 2007, pp. 326-342). During recessionary times, it has been observed that companies, who carry out an extensive Research and Development, are found to be very active in their performance since they must have foreseen the situation and adopted coping mechanisms (Leong et al., 2008, pp. 996-100). A careful control over R\&D capabilities could positively react towards crisis by changing their returns on the common equity. In case the company pursues long-term growth in its sales, managers must not cut back on their budgets allocated to Research and Development during slowdown periods. Two profound strategies that could be used in recessionary periods are to offer high quality products at same prices, or to sell same quality products at lower prices. However, pricing decisions must be integrated with other initiatives of the marketing mix in times of recession.

\subsection{Dimensions of Effective Marketing}

Imagine a situation in which marketers would be able to capitalize upon the Return on Investment (ROI) for every dollar they spent. Planning cycles are accelerated with streamline planning a matter of just few weeks (Narver et al., 1998, pp. 241-243). In such a case, marketers would imagine and predict the increments in revenues long before a single penny on the project is spent. In order to make these dreams come true, an active and focused approach of each marketer is necessary (Holtzman et al., 2007, p. 60). With the execution of tactics, strategies and related campaigns, managers need to ascertain the impacts that their proposed strategies may have on the business. Their struggle should optimize so as to transform their marketing actions into meaningful business results and an increased profitability.

Following are some dimensions of effective marketing that can facilitate the marketers in focusing on results while being proactive towards the changing marketplace phenomenon: 
- Planning scenarios that directly affect revenue goals and their attainment;

- Collaborating between the scheme and its developmental programs (Sachs et al., 1996).

Prudent consumers-They have high risk attitude although they do not perceive risk in crisis. These individuals postpone big purchases in crucial times while being extremely well-informed about the pros and cons of their buying decisions. They are certainly not stressed out due to previous avoidance of riskiness.

\subsection{Consumer's Emotional Responses towards Crisis in Turkey}

Various consumers react to crisis in different ways; which leads towards a drastic change in consumption patterns. Majorly, there are six types of emotional responses that consumers show amidst a crisis state of the economy:

Continue same behaviors: There are some consumers who have enough income that does not change in the face of an economic crunch. For these consumers, consumption patterns does not need to be rethought of; they may not be willing to react towards external economic pressures that would otherwise, have impacted upon their patterns of consumptions (Matute et al., 2011, pp. 317-319).

Reduce spending to "survive": This is the commonest emotional response in which consumers reduce their spending and consume as less as possible so that they may survive in the wake of economic instability in their state (Matute et al., 2011, p. 320). To cope up with crisis, consumers showing this emotional stimulus lessen their purchases or postpone expensive purchases for future, avoid purchases that are not essentially- required, and even down downgrade quality by switching off to cheaper alternatives.

Save by reducing spending: This is an anticipating kind of consumers who expect the future conditions to worsen, and so, they reduce consumption in the form of either product quantity or quality (by switching to alternatives that are less pricey). These consumers allocate some portions of their income to savings and avoid unnecessary purchases in an expectation of more adverse economic state (Matute et al., 2011, p. 323).

\section{Research Methodology}

This study includes the administration of a questionnaire-based survey method to collect data in order to study how effective target marketing strategies can help combat Turkey's crisis. As is famous in all types of marketing research, questionnaires have been considered as the most feasible method of data collection in this specific context, since the researcher can obtain responses from marketers, managers and consumers in different Turkish companies. The sample will comprise of marketers and managers in different Turkish companies who will be randomly asked to fill out the questionnaire that contains fifteen close-ended questions. These employees will belong to the managerial level of organizational hierarchy, belonging to the department of marketing and marketing intelligence. Among the 50 participants selected for this research 21 are the on the post of marketing manager at different organizations and 12 are other marketing experts. While 3 forms filled by CMO (chief Marketing officer) of different companies and 9 are the different employees working in marketing department. 
Although out of 50 participants 5 are the local marketers from different shops. The respondents will be chosen from organizations that fall within the Business-to Consumer (B2C) category. The reason behind choosing B2C companies is because they comprise of large numbers of consumers/customers who base their purchasing decisions on emotions, and show different responses and tendencies to similar marketing tactics. This type of marketing is more volatile and is heavily influenced by changes in purchasing powers of customers in crises situations. Random-sampling is a probability sampling method that is convenient to analyze and gives equal chances of participation to the respondents.

\section{Study Limitations}

Time constraints were faced by the researcher since the researcher had to conduct this entire study within a specific time deadline. The survey instrument in data collection was only distributed amongst Turkish companies, and so this study cannot be generalized to any other state except for Turkey.

Lack of reliable data is a possible study limitation since the quality of marketing research depends on the data quality. If up-to-date data was readily available, then marketing research such as this could have been efficiently prepared; otherwise, this might be a problem to reach and use accurate and reliable data.

\section{Finding and Analysis}

Turkey has been facing numerous economic and political challenges in the recent years followed by the current era in which it is experiencing stability and solid growth in its economy. The country has still untapped potential to grow at the rate of $5 \%$ every year in the medium term. The research conducted has resulted into a number of key observations that has truly facilitated the researcher in achieving the key research questions and objectives from this study. Turkey's world-class features include its strategic location at the crossroads of Europe, Asia and the Middle East, and the size of its domestic market has turned out to be solid opportunities to entrepreneurs who are entering into new business ventures in the country.

Following is a systematic interpretation and reporting on the findings of the questionnaire based survey. Each question is followed by the graphical representation of its responses after which a brief interpretation is mentioned so that readers are able to "read" the findings by looking through the graphs. This chapter is sub-divided into two parts: Findings and Analysis. The first section has been dedicated to reporting actual data while the second section is devoted to analyzing what has been found through the survey instrument.

\subsection{Findings \& Graphical Presentation of Respondent Data}

Following is a systematic interpretation and reporting on the findings of the questionnaire based survey. Each question is followed by the graphical representation of its responses after which a brief interpretation is mentioned so that readers are able to "read" the findings by looking through the graphs. This chapter is sub-divided into two parts: Findings and Analysis. The first section has been dedicated to reporting actual data while the second section is 


\section{Macrothink}

devoted to analyzing what has been found through the survey instrument.

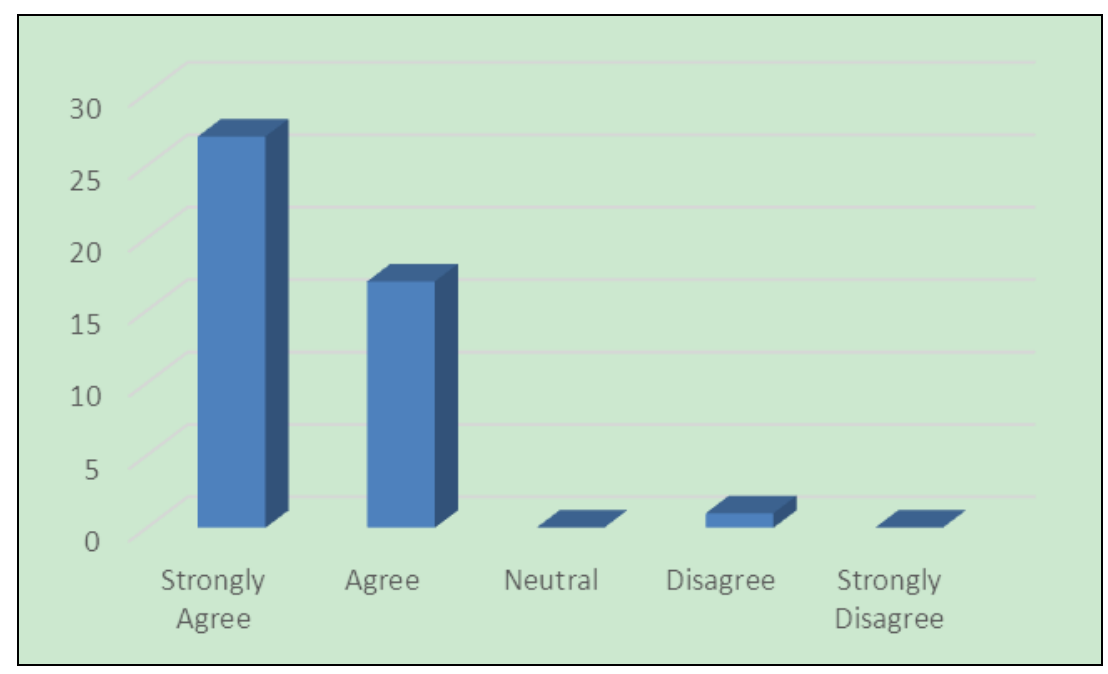

Figure 1. During economic crisis, consumers' buying patterns have greatly been changed in Turkey with the trend shifting towards price substitution and Do-It-Yourself (DIY) buying practices.

The question of this survey related to inquiring the buying patterns of customers, stating that substitution prices and DIY practices become a norm during crisis. Consumer substitution behavior refers to the concept that as there occurs an increment in prices of certain products; consumers may divert or switch towards substitutes that offer a different brand in a similar product category, but at relatively lower prices. This has been a commonly-observed phenomenon in the Turkish marketplace where a crisis-stricken customer often resorts to this practice of purchase as a remedy to overcome financial constraints. The adoption of substitution behavior to compensate for all purposes in comparison to brands offering expensive products has so far, been questioned in research circles. This ambiguity and speculation regarding its adoption had led the researcher to include such a question in this survey so that a proper answer may be obtained.

Consumers often resort to these two practices as immediate changes in their buying patterns occur over this time. With a minority disagreeing to such consumers, the researcher was compelled to assume that those marketers may have observed a loyalty with brands even in case of crisis situations. 


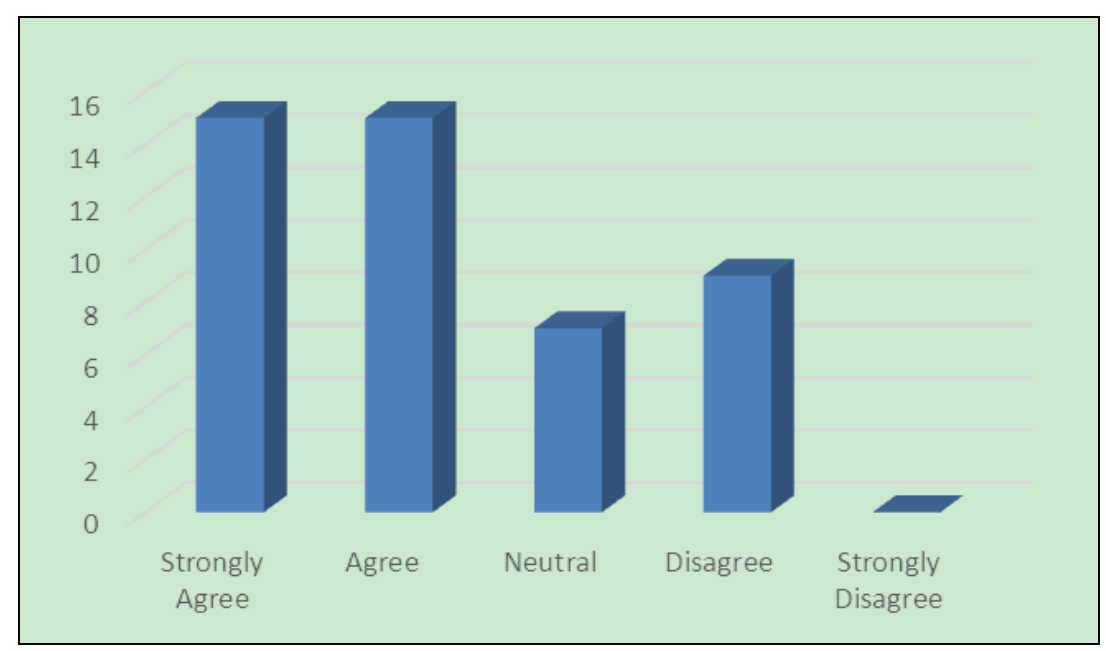

Figure 2. Strategic decisions in terms of productivity, market shares and sales revenue can help improve a company's approach in dealing with crisis

The question in the survey was purely based on a company's approach towards dealing with the crisis, asking the participants to respond if their choices in a critical situation is only based on increasing productivity while cutting costs, seeking more shares in the market and diversifying or undertaking other approaches so that sales revenue may be increased. To this question, $32 \%$ of the total respondents strongly agreed that these approaches help them in dealing with the crisis, while the other $32 \%$ also agreed, although with less forcefulness. Surprisingly, 10 respondents disagreed to the statement which led the researcher to doubt if factors other than these, contribute towards tackling with the instability situations.

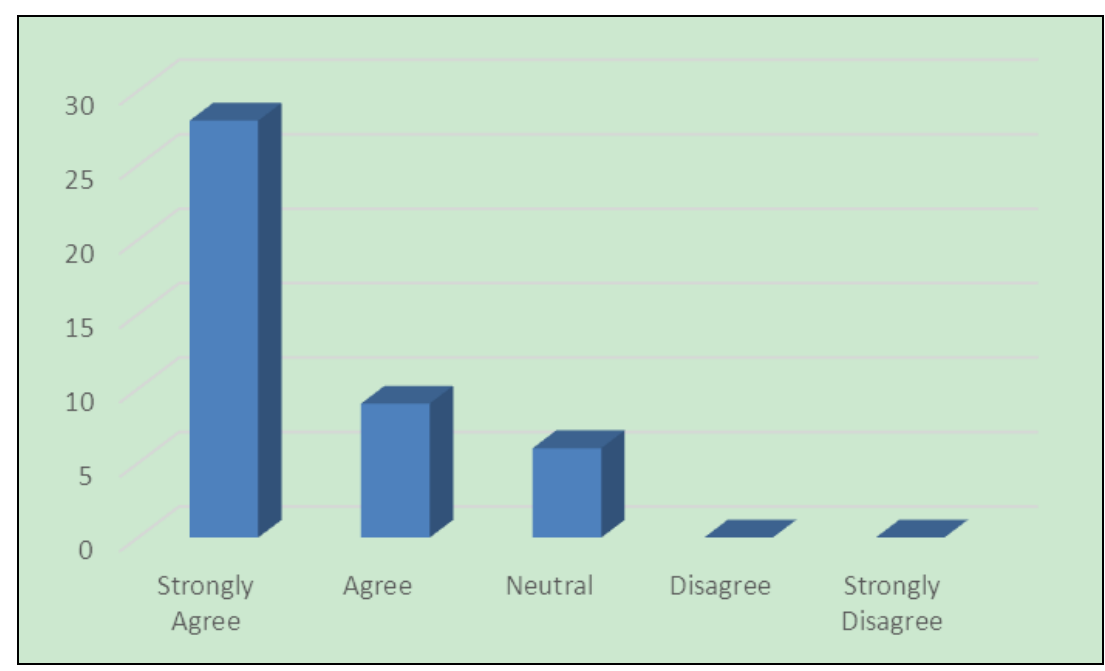

Figure 3. Turkey, in lieu of economic instability, needs to accelerate its capabilities in Research and Development (R\&D) so as to increase and enhance the country's attractiveness for Foreign Direct Investments (FDIs) 


\section{I Macrothink}

World Journal of Business and Management

ISSN 2377-4622

2015, Vol. 1, No. 1

The urgency of increasing scope and attractiveness for FDIs has been the central point behind the formulation of this specific question. The researcher has specifically placed value in developing and enhancing the R\&D sector of businesses operating in Turkey, so as to gauge their efforts towards FDI opportunities and its relative factors. A vast majority of respondents (30 out of 50) strongly agreed to the need of dedicating more time and resources towards enhancing the R\&D of Turkish business firms. 12 others agreed this statement to be true, helping the researcher to study its importance in relation to other factors. 8 participants of the study were of mixed opinion whether or not Turkey should devote its attention towards R\&D and not saturate the efforts towards other facets of economic development and strategic decision-making. Nobody disagreed to the statement, on the whole.

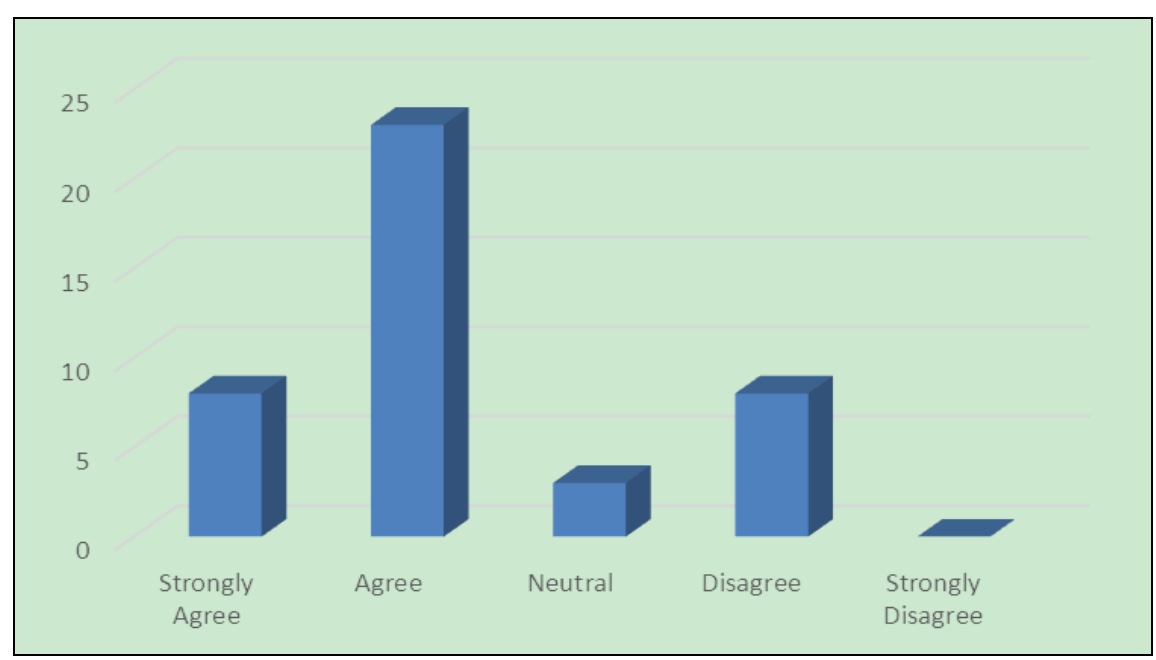

Figure 4. The country's favorable geographical location and larger market drives are key benefits that are yet to be utilized by the companies working within

Situated at the crossroads of Asia, Europe and the Middle East, Turkey provides excellent opportunities for business firms both on immediate basis and in the long-term. Turkey's geographic location, followed by a growing market share of consumer middle class offers numerous international businesses with sound growth opportunities that are seldom seen elsewhere. Due to this reason it was essential to inquire from the respondents whether or not they perceive these traits as positive benefits for the economy. $50 \%$ of the total responses attained in this regard, were in affirmed agreement to the fact that R\&D planning in the sector will prove to be very successful in generating sound business opportunities while its geography and market share opportunities will be advantageous to new entrants in the Turkish business sector. The country has emerged as a growing business platform given the fact that its entrepreneurial class is ever-flourishing. On the other hand, the researcher observed that almost 10 people out of 50 respondents did not agree that the country's favorable geographical location and larger market drives are key benefits that are yet to be utilized by the companies working within. 


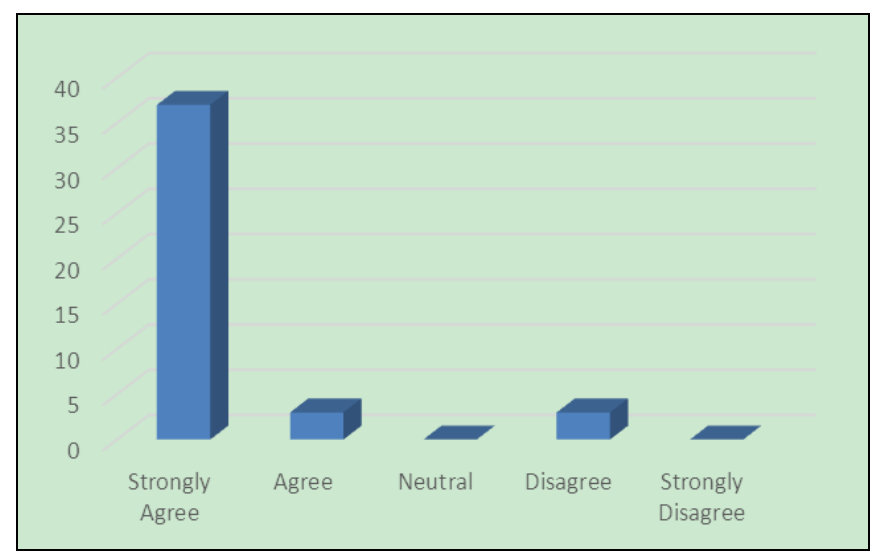

Figure 5. Economic turmoil in Turkey gave birth to key concerns such as high budget deficits and inflation which is restricting the home industries to flourish

The question of this survey was dedicated to getting respondents' views regarding the key concerns identified as the main effects of economic turmoil in Turkey. These two issues have been identified to have affected domestic industries and enterprises in a negative manner, restricting their growth and posing threats in their goal of growth and profitability. Costs being higher in an economic downturn time period, hinders in the way of domestic businessmen who finds it hard to break-even. As per the changing customer preferences, it has been observed that customers rarely tend to switch to domestic produce if the international brands are offering cheaper alternatives. 40 respondents had strongly agreed to this phenomenon contending they believe these are the determining factors that impede in the way of success for local industries. Only 5 respondents out of the entire sample disagreed with the statement and there might be some other reasons behind their opinion that could have been regarded as more deadline in the way of progress of domestic manufacturers and service providers.

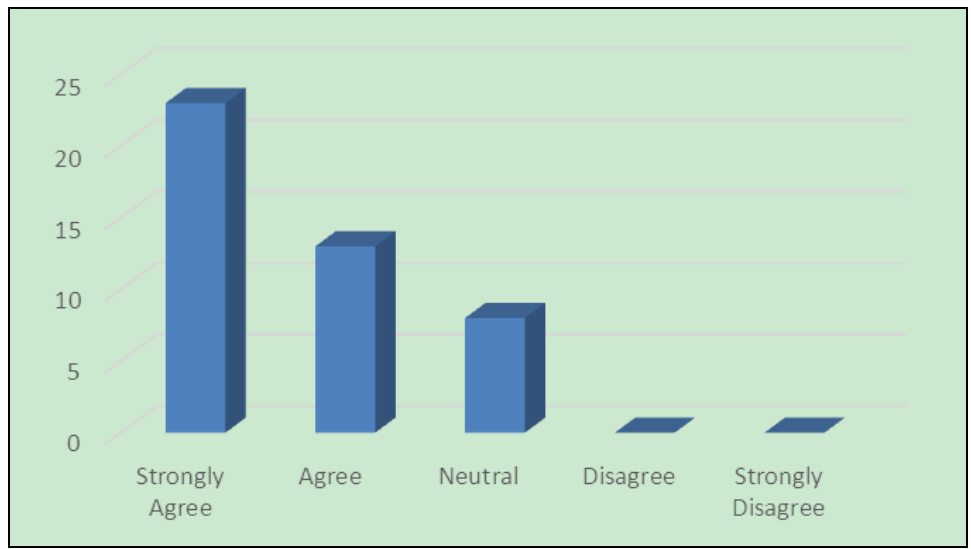

Figure 6. Sound regulatory and supervision reforms in the country can build Turkey's resilience against economic shocks, making it one of the largest business economies of the world 


\section{NIMacrothink}

The question in the survey aimed at evaluating the role of regulatory reforms and governmental support in helping Turkish businesses flourish and recoup after crisis. As per the statement of the survey mentioned here, it was asked whether or not the respondents agreed that supervisory reforms and other regulatory bodies can help the Turkish industry in absorbing the shocks of the crisis and exhibit resilience against the pressures. To this statement, a wide majority of respondents affirmed that indeed, supervisory reforms and other regulations can help the industry to recover from the challenges in the economy in a triumphant manner. It is therefore, assessed that in the presence of strong outlaws regarding the development and recovery measures taken by the Turkish government, the industry will resume on the track to progress and will compete with international competitors, provided that its structure and operations are carefully assessed and systematically planned keeping in mind all aspects of a successful crisis management strategy.

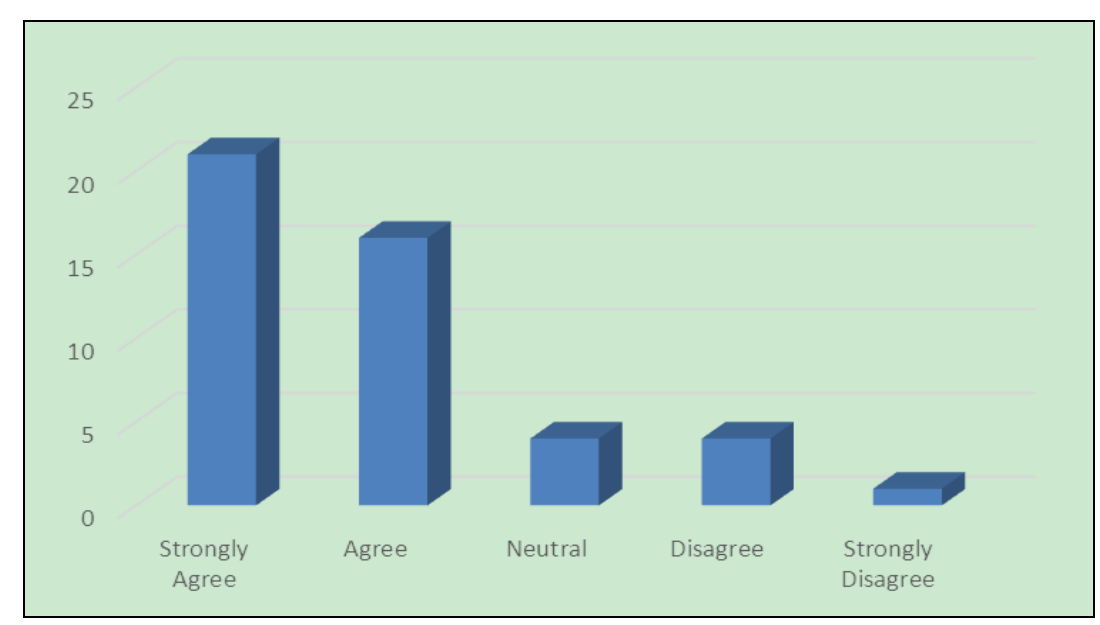

Figure 7. Strong private sector and growth of Small and Medium-sized Enterprises (SMEs) are key initiatives that marketers need to pay attention to, in order to formulate effective target marketing strategies and positioning tactics within the Turkish business markets

The question in this survey was related to finding out the role and contributions of the growth of private sector and the SMEs in boosting the Turkish marketplace so that marketers are able to devise strategies that could outperform the competitors in times of economic distress. An assessment of the investment climate is highly crucial to study the essentiality of these factors in the overall production during crisis times. It was sue to Turkey's resilience in crisis times that is greatly owed to the position and structural reforms of the macroeconomic sector, along with reforms in business regulations as previously discussed. 


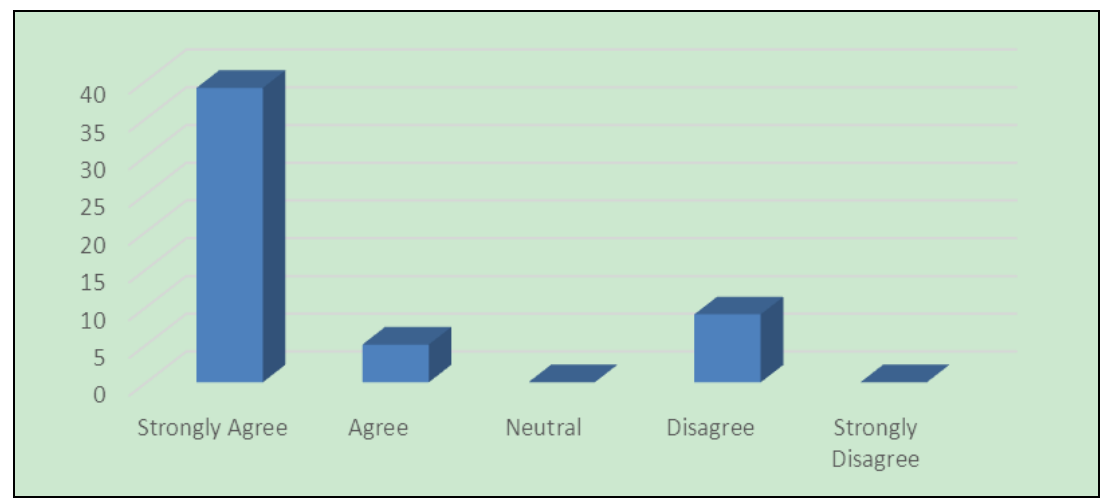

Figure 8. "Trust" and "value for money" are key themes in a crisis time; reflecting that marketers need to integrate these two factors in their strategies so as to effectively developing coping mechanisms

The question of this survey was aimed at evaluating how much Turkish organizations value the trust-building as an essential component of crisis management. We had discussed during the course of this work that relationship building is highly essential in giving the customers what they want, and connecting with them for better outcomes. Without giving the customers, the value for their money (in terms of carefully-designed products and services) along with creating a feeling of mutual trust and cooperation, companies cannot succeed in a competitive era as of today. A lack of accurate information and mutual connectivity between these parties impact upon the tendency of customers to make complaints and influence word-of-mouth promotions. An inability to understand the customers and not delivering as per their expectations lead to a dissatisfied customer, who might think the company does not appreciate or rather acknowledge his presence; compelling him to switch to other alternatives. The entire response set of this particular question was in sheer affirmative whereby 42 respondents strongly agree that if companies pay attention to these two points, they can surely succeed in combating the vices of a crisis.

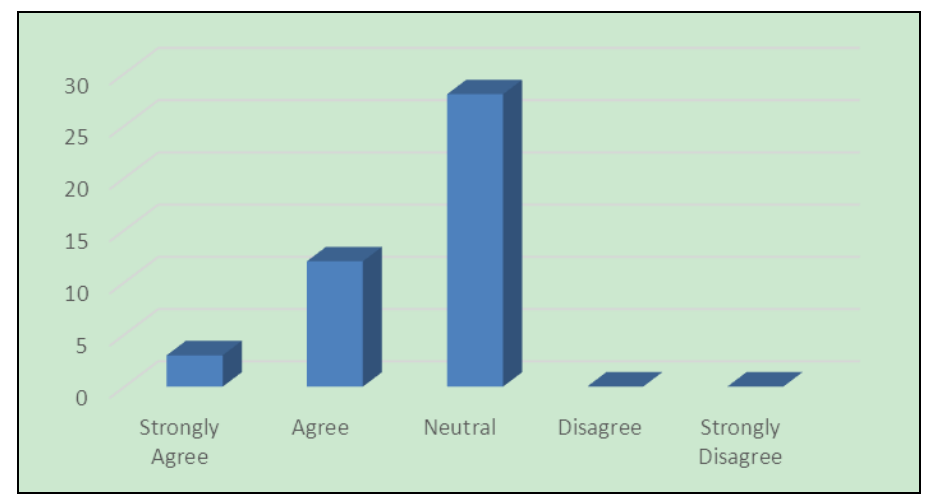

Figure 9. A current market observation tends to support the idea that if companies keep on increasing their marketing spending even during a crisis, they do not suffer from losses and even gain more market shares once the crisis subsides 


\section{Al Macrothink}

World Journal of Business and Management

ISSN 2377-4622

2015, Vol. 1, No. 1

This part of the questionnaire was motivated by the idea that marketing expenses does not tend to decline even when companies suffer from crisis and turmoil. Even in turbulent economic periods, companies do not normally cut down on their promotional budgets, expecting that they would still be able to capture untapped markets. This question majorly received a neutral opinion, indicating that the respondents neither disagreed nor agreed to it. On the other hand, none of the respondents chose to strongly disagree or even disagree on the theme, indicating that on the overall, respondents' affirmation could generally be assumed.

Despite the fact that during an economic turbulence, there is a tendency to cut down upon the advertising costs, firms should refrain from doing so. In a post-crisis situation, only those companies will be winning the game who knows how to enhance their promotional campaigns in the most effective manner, while maintaining the budgetary allocations for the marketing department. In lieu of a motive to cut down upon the costs of a business, usually, the marketing department comes first in the minds of senior management. However, with the advent of new user-friendly and cost-effective promotional technologies and platform such as the social media networking, it has been realized that promotional efforts need not be stooped even during financial constraints. Companies that realize the significance of marketing budgets and marketing activities during the crisis are usually the ones who enjoy larger market shares once the crisis subsides.

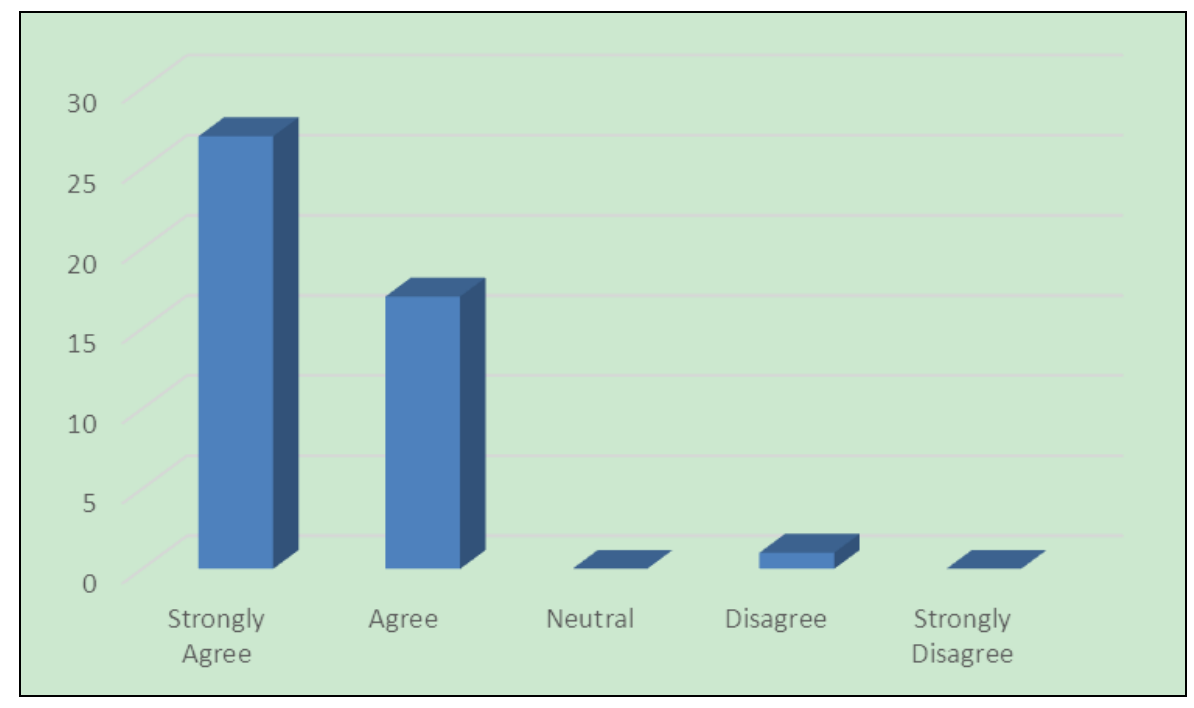

Figure 10. Crisis affects customers not only financially, but also psychologically. Effective target marketing and positioning therefore, calls for an approach to promote products based on their psychological effects and benefits

Economic downturns hit people psychologically, more than financially. Marketers observe radical changes in consumer buying practices as soon as they are struck by a crisis situation. In such a situation, they do not enjoy shopping, and rather restrict or even limit their purchases. Having uncertainties in mind, these consumers worry about their futures, and 
revise their budgets, subtracting an involvement (through purchasing) of luxury goods. One of the most instantaneous effects is a rational view of purchasing and shopping, while these consumers do not spend on premium offerings anymore. They are more volatile in nature after the crisis strikes, and a slight glitch in not being able to deliver optimal customer value can go a long way in permanently losing them. Customers, during crisis, prefer commercials being informative rather than fancy. Companies should clearly deliver promotional activities keeping in mind the psyche of the intended target markets, so that information regarding products' features, durability, safety and reliability is promoted in relation to its appearance and outlook. This goes a long way in creating trust amongst customers, something that is even more profitable for marketers than huge budgets without a clear-cut focus.

\section{Conclusion \& Recommendation}

The researcher conclude and appraise the role of effective target marketing and helping marketers, study how they can best conduct target marketing in a "crisis-stricken" country as Turkey. This research study is an indicator of the fact that economic crisis influences consumer purchasing powers; thus, becoming a point of concern for marketers to bring about sustainable changes to their marketing strategies in accordance with the changing landscapes. This research showed s shift in consumer behaviors in lieu of stressful times when they rethink about purchasing items, assessing its actual worth and evaluating how they want to live (with or without it). The researcher witnessed a slowdown in the consumption patterns of consumers followed by the crisis in Turkish markets, which has significantly impacted upon the brands and their positioned perceptions amongst the Turkish people. There are some following recommendations for Turkish companies while doing their Marketing in crises situation.

- Marketers should build up and develop a team of experts who can audit and monitor the effectiveness of the marketing activities as reflected in the Return on Investment (ROI).

- Product portfolios need to be reconsidered during crisis times. Effective target marketing planning involves looking across to find new geographic opportunities, new consumer groups and more categories of products as the time demands. During crisis times, consumers pay more attention to the prices they get on the shelves which is why brands should offer money-saving impressions by launching discounted offers and deals that tend to attract customers.

- Marketers should specifically target low-income consumers in recession times as they are more susceptible towards switching off to alternative and cheaper brands. Re-launching existing brands with features that promote a low priced option is naturally a good idea.

- During an economic crisis, marketers need to promote the functional, as well as, the emotional benefits of products so as to communicate "value" amongst the potential consumers. This will solely be done because their preferences tend to alter or shift here and there, during a turmoil period; it is very easy to divert to other, economical offers in the absence of a proper communication plan by the existing brand with regards to the functionality they offer, as well as, the emotional benefits that need to be reinforced. The 
relevance of a brand needs to be updated during crisis by altering the features as per consumers' changing habits of consumptions or their preferences.

- Marketers must work towards reassuring their consumers that they are making smart choices by choosing their brands as they offer value against the spent money. As consumers look towards safety, reliability and functionality in crisis, they might also buy luxury items on an occasional basis so as to cheer their beloveds.

- Product differentiation takes on its motivation from value innovation during hard times. During an economic turndown, it becomes highly essential to seek new distribution channels, reduce costs, and make the product more accessible and cost-effective. Innovative marketing ideas need proper implementation during economic turmoil, so that the situation turns out to be an opportunity for the brands.

- The best time to follow on and connect with your customers is during an economic turmoil. As customers move on towards shopping habits and new channels of retail, companies should bring some changes in their strategies with respect to distribution channels and other such areas. Businesses can take advantage from this situation and connect closely to them by getting to know their needs and wants better. Launching target marketing campaigns using social media networking platforms, mobile devices and Internet promotional schemes, marketers can better sense the needs of their customers and resolve to commit themselves to better customer care and service.

- Digital media is an extremely lucrative opportunity in a crisis time, whereby this platform offers opportunities in the form of building communities on the Web that can help foster a long-term commitment and relationship with the customers and help marketers to deal with the situation in an improved manner.

The study concludes that despite all financial constraints, the budget that is spent on Research and Development of new markets must not be reduced in any case. This reduces the impositions of crisis on a company, and helps in recovering from economic distress. Moreover, the Turkish firms should improve and develop distinctive set of strategic choices so that they are in a better position to absorb shocks from recessionary periods in the overall economic stagnancy. Taking the perspective of Turkish organizations, it will be very fruitful if the companies focus their R\&D on developing new products for a niche market, and implement technological solutions that restrict costs incurred. It can be concluded that Turkey's solid financial institutions, its favorite geographic location, growing consumer middle class and strong entrepreneurial activities are few opportunities that are the sole reasons why investors are still placing a lot of confidence in the future of Turkish markets, despite being struck by the adversities of economic crisis.

During an economic crisis, marketers must keep investing in their main brands to serve their "loyal" customers in a better manner. This calls for a very clear value proposition that can help target markets in the face of price-cutting demands. In this case, marketers can do their task efficiently while being "unharmed" by the pressures of a crisis situation. A very important area of consideration is brand communications which tend to increase brand image as marketers work towards promoting more positive messages about their brands. It has been 
a general observation that when brands increase their advertising and promotions amidst recession, while their competitors are cutting back on their costs, can gain more shares in the market and get more returns on their investments at a much low cost than they achieve during stable economic conditions.

\section{Acknowledgements}

The research is sponsored by Europe-e-Union (Erasmus scholarship program) and conducted at Istanbul Aydin University and University of Applied Science Landshut Hochschule Germany. Thanks to the Europe-union for giving me the opportunity and make be able to conduct this research in multi culture environment under the guidance of different countries professors. I would like to say thanks to the different departments includes Easmus department and International department of Istanbul Aydin University and Landshut Hochschule University of Applied Science Germany.

\section{References}

Allsop, D. T., Bassett, B. R., \& Hoskins, J. A. (2007). Word-of-mouth research: principles and applications. Journal of Advertising Research, 47(4), 398-410. http://dx.doi.org/10.2501/S0021849907070419

Amalia, P., \& Ionut, P. (2009). Consumers' reaction and organizational response in crisis context. The Journal of the Faculty of Economics, 1(5), 779-782.

Bifulco, A., \& Brown, G. W. (1996). Cognitive coping response to crises and onset of depression. Social Psychiatry and Psychiatric Epidemiology, 31(3-4), 163-171. http://dx.doi.org/10.1007/BF00785763

Burnett, J. J. (1999). A strategic approach to managing crises. Public Relations Review, 24(4), 475-488. http://dx.doi.org/10.1016/S0363-8111(99)80112-X

Chorafas, D. N. (2009). Financial boom and gloom: The credit and banking crisis of 2007-2009 and beyond (pp. 50-65). New York: Palgrave Macmillan. http://dx.doi.org/10.1057/9780230235830

Coombs, W. T. (2007). Protecting organization reputations during a crisis: The development and application of situational crisis communication theory. Corporate Reputation Review, 10(3), 163-176. http://dx.doi.org/10.1057/palgrave.crr.1550049

Copulsky, J. R., \& Wolf, M. J. (1990). Relationship marketing: Positioning for the future. Journal of Business Strategy, 11(4), 16-20. http://dx.doi.org/10.1108/eb060069

Creswell, J. W. (1999). Mixed-method research: Introduction and application. In G. J. Cizek (Ed.), Handbook of educational policy (pp. 50-250). San Diego: Academic Press. http://dx.doi.org/10.1016/b978-012174698-8/50045-x

De Ruyter, K., Van Birgelen, M., \& Wetzels, M. (1998). Consumer ethnocentrism in international services marketing. International Business Review, 7(2), 185-202. http://dx.doi.org/10.1016/S0969-5931(98)00005-5 


\section{$\triangle$ Macrothink}

World Journal of Business and Management

ISSN 2377-4622

2015, Vol. 1, No. 1

Duncan, R. (2005). The dollar crisis: Causes, consequences, cures (pp. 10-100). Singapore;

Hoboken, NJ Chichester, England: J. Wiley \& Sons (Asia). http://dx.doi.org/10.1093/acprof:oso/9780199257430.003.0004

Eichengreen, B. J. (2002). Financial Crises: and what to do about them (pp. 101-133). Oxford:

Oxford

University

Press.

http://dx.doi.org/10.1093/acprof:oso/9780199257430.003.0004

Eisner, E. W. (1991). The enlightened eye: Qualitative inquiry and the enhancement of educational practice (pp. 33-109). Old Tappan, NJ: Macmillan.

Erickson, F. (1986). Qualitative methods in research on teaching. In M. C. Whittrock (Ed.), Handbook of research on teaching (3rd ed., pp. 119-161). Old Tappan, NJ: Macmillan.

Ertuğrul, A., \& Selçuk, F. (2001). A brief account of the Turkish economy, 1980-2000. Russian and East European Finance and Trade, 6-30.

Farlow, A. (2013). Crash and beyond: causes and consequences of the global financial crisis (pp. 173-300). Oxford University Press. http://dx.doi.org/10.1093/acprof:osobl/9780199578016.001.0001

Flyvberg, B. (2006). Five misunderstanding about case-study research. Qualitative Inquiry, 12(2), 219-245. http://dx.doi.org/10.1177/1077800405284363

Fredrickson, B. L., Tugade, M. M., Waugh, C. E., \& Larkin, G. R. (2003). What good are positive emotions in crisis? A prospective study of resilience and emotions following the terrorist attacks on the United States on September 11th, 2001. Journal of Personality and Social Psychology, 84(2), 365. http://dx.doi.org/10.1037/0022-3514.84.2.365

Gobo, G. (2004). Sampling, representativeness and generalizability. In C. Seale, G. Gobo, J. F. Gubrium, \& D. Silverman (Eds.), Qualitative research practice (pp. 435-456). London: Sage. http://dx.doi.org/10.4135/9781848608191.d34

Grewal, R., \& Tansuhaj, P. (2001). Building organizational capabilities for managing economic crisis: The role of market orientation and strategic flexibility. Journal of Marketing, 65(2), 67-80. http://dx.doi.org/10.1509/jmkg.65.2.67.18259

Guba, E., \& Lincoln, Y. (1981). Effective evaluation (pp. 100-145). San Francisco: Jossey-Bass.

Hamel, J. (1993). Case Study methods. Qualitative Research Methods, 32. Thousand Oaks, CA: Sage.

Holtzman, B., Hughes, C., \& Van Meter, K. (2007). Do it yourself" and the movement beyond capitalism (pp. 44-61). Constituent imagination: Militant Investigation/Collective theorization. Johnson, W. (2011). International economic freedoms, banks and the market crisis of 2007-2009. Journal of Banking Regulation, 12(3), 195-209. http://dx.doi.org/10.1057/jbr.2011.8

Kaminsky, G. L., \& Schmukler, S. L. (1999). What triggers market jitters? A chronicle of the 
Asian crisis. Journal of international money and Finance, 18(4), 537-560. http://dx.doi.org/10.1016/S0261-5606(99)00015-7

Koelemeijer, K., Vlachos, P., \& Koritos, C. (May 2013). Consumer ethnocentrism: A cure or a curse for EU debt crisis? Business Review Europe, 12(5), 12-20.

Köksal, M. H., \& Özgül, E. (2007). The relationship between marketing strategies and performance in an economic crisis. Marketing Intelligence \& Planning, 25(4), 326-342. http://dx.doi.org/10.1108/02634500710754574

Yin, R. K. (1992). The case study method as a tool for doing evaluation. Current Sociology, 40(1), 23-137. http://dx.doi.org/10.1177/001139292040001009

\section{Copyright Disclaimer}

Copyright for this article is retained by the author(s), with first publication rights granted to the journal.

This is an open-access article distributed under the terms and conditions of the Creative Commons Attribution license (http://creativecommons.org/licenses/by/3.0/). 